\title{
LAYANAN KONSELING KELOMPOK DALAM MENINGKATKAN PSYCHOLOGICAL WELL-BEING REMAJA DI LEMBAGA PEMBINAAN KHUSUS ANAK (LPKA) PANGKALPINANG
}

\author{
Siska Dwi Paramitha \\ IAIN Syaikh Abdurrahman Siddik Bangka Belitung, Indonesia \\ siska.psi86@gmail.com
}

\begin{abstract}
Psychological well-being is needed by every individual. Psychological services are needed to achieve prosperity in psychology, one of which is group counseling services. In this case, adolescents who are in the Special Correctional Institution for Child (Lembaga Pembinaan Khusus Anak, LPKA) need to improve psychological well-being which hopes of being able to return to their role and get good acceptance in the community or social environment. This research is experimental research by a pre-experimental design-one group pretest-posttest design. The treatment given in the form of group counseling services and given questionnaires before and after treatment was given. There were 17 subjects in which group counseling services had never been done before at LPKA. Data analysis used the t-test and Gain Score. The results showed the psychological well-being of adolescents significantly no increase given to group counseling services. But, if you see the gain score data, it was found that 7 of 17 subjects experienced an increase before and after being given group counseling services.
\end{abstract}

[Psychological well-being amat dibutuhkan oleh setiap individu. Untuk mencapai kesejahteraan psikologis, maka dibutuhkan layanan-layanan psikologi yaitu salah satunya layanan konseling kelompok. Dalam hal ini remaja binaan yang berada di Lembaga Pembinaan Khusus Anak (LPKA) membutuhkan peningkatkan psychological well-being dengan harapan dapat kembali berperan dan mendapatkan penerimaan yang baik di masyarakat atau lingkungan sosial. Penelitian ini merupakan penelitian ekperimen (experimental research) dengan bentuk preexperimental design-one group pretest-posttest design. Dimana perlakuan yang diberikan berupa layanan konseling kelompok dan diberikan kuesioner sebelum dan sesudah diberikan perlakuan. Subjek penelitian berjumlah 17 (tujuh belas) orang dimana layanan konseling kelompok belum pernah dilakukan sebelumnya di LPKA. Analisis data pada penelitian ini menggunakan Uji-t dan Gain Score. Hasil penelitian menunjukkan tidak terjadinya peningkatan yang signifikan pada psychological well-being remaja yang diberilakan layanan konseling kelompok akan tetapi jika melihat data gain score maka didapatkan 7 dari 17 subjek mengalami 
peningkatan sebelum dan sesudah diberi perlakuan layanan konseling kelompok.]

Keywords: Group counseling services, Special Correctional Institution for Child (LPKA), Psychological well being, Pre-experimental design-one group pretest-posttest design

\section{A. Pendahuluan}

Memasuki era milenial, berbagai permasalahan baik di kota maupun di desa semakin meningkat. Mulai dari permasalahan pendidikan, ekonomi, keluarga dan masih banyak lainnya. Sumber dari permasalahan saat ini bukan hanya dilakukan oleh orang dewasa saja namun golongan remaja dan anak-anak sudah mulai mampu berbuat kejahatan yang melanggar hukum. Berdasarkan catatan Komisi Perlindungan Anak (KPAI), mulai dari tahun 2011 sampai dengan 2018 terkait tentang Anak Berhadapan Hukum (ABH) selalu berada diperingkat teratas dan tidak pernah dibawah 1000 kasus ditiap tahun, baik anak yang menjadi korban maupun sebagai pelaku. Kasus yang ditangani juga bermacam-macam salah satunya anak sebagai pelaku kekerasan seksual masih menjadi kasus paling tinggi dan diikuti kasus kekerasan fisik serta pembunuhan. ${ }^{1}$

Saat Anak Berhadapan Hukum sudah melalui proses persidangan, sebaiknya memang anak mendapatkan perlindungan baik dari lembaga Pemerintahan, psikolog atau konselor dan tentunya orangtua karena dalam penyelesaian masalah yang dihadapi di kehidupan sehari-hari apalagi sudah menyangkut tentang hukum tentunya membutuhkan bantuan dari orang lain karena pada dasarnya disaat seseorang sedang menghadapi suatu permasalahan, biasanya orang tersebut kurang mampu berpikir dengan jernih, emosi labil, frustasi sehingga kurang mampu mengambil keputusan dengan baik yang akhirnya berdampak pada keputusan yang salah dan terkadang melakukan perbuatan anarkis. Dalam hal keprofesionalan, kasus khusus tentu perlu penangan khusus dan juga orang-orang yang khusus. Salah satunya penangan

${ }^{1}$ Widia Primastika, Penyebab Kriminalitas Anak: Kurang Kasib Sayang \& Pengakuan Sosial, s29 Juli 2018, bttps:// amp.tirto.id/penyebab-kriminalitas-anak-kurang-kasih-sayang-pengakuan-sosial-cP3FI. Diunduh 11 Maret 2019. 
Layanan Konseling Kelompok dalam Meningkatkan Psychological Well-Being Remaja di Lembaga Pembinaan Khusus Anak (LPKA) Pangkalpinang

permasalah khusus ini dapat melalui layanan konseling yang ditangani oleh konselor ataupun psikolog.

Masing-masing bagian memiliki peran penting dalam melindungi pelaku maupun korban. Di pulau-pulau besar, seperti pulau jawa banyak tenaga-tenaga profesional yang bisa melakukan perlindungan tersebut mulai dari layanan hukum gratis oleh para advokat, layanan konseling gratis oleh para psikolog maupun konselor yang tentunya memang telah disediakan oleh pihak kelembagaan. Penerapan dari layanan-layanan tersebut salah satunya adalah layanan konseling.

Layanan konseling saat ini sudah banyak dibutuhkan keberadaannya, mulai dari sekolah, puskesmas, rumah sakit, lembaga-lembaga pemerintah dan lainnya. Tidak dipungkiri di kota besar maupun wilayah maju memang sudah banyak melakukan layanan tersebut diantaranya: Jakarta, Yogyakarta, Jawa Timur, Jawa Tengah, Jawa Barat, dan Sumatera Barat. Namun, di Provinsi Kepulauan Bangka Belitung khususnya Pangkalpinang masih sangat minim keberadaan layanan konseling ini dan masyarakat belum banyak memahami pentingnya keberadaan layanan konseling. Jumlah tenaga psikolog khususnya psikolog klinis pada tahun 2011 sebanyak 365 orang, jumlah standar rasio kuota minimal yang ditetapkan WHO, yaitu 22:100.000 dan konslelor 1:30000². Menurut Himpunan Psikologi Indonesia (HIMPSI), jumlah anggota saat ini yang tersebar di seluruh Indonesia mulai dari sarjana psikologi, magister psikologi, doktor psikologi dan psikolog sebanyak 11.500 orang, bahkan jumlah psikolog klinis tidak mencapai 10 persen dari angka tersebut, yaitu 1.143 orang per mei tahun $2019 .^{3}$

Di Bangka Belitung sendiri, jumlah tenaga psikolog klinis berjumlah 16 orang dengan jumlah penduduk di bangka belitung saat ini sebanyak 1.488 .792 orang$^{4}$. Dimana para psikolog tersebar di beberapa wilayah antara lain Pangkalpinang,

2 Julianto Simanjuntak, 1 Pusat Konseling di Setiap Kota. 3 Februari 2016, http:/ / juliantosimanjuntak.com/index.php/artikel/ renungan-catatan-harian/237-1-pusat-konsleing-di-setiap-kota , Diunduh tanggal 11 Maret 2019.

3 Aulia Adam, Defisit Psikiater dan Psikolog Sebarannya Terpusat di Jawa. 6 Mei 2019. bttps:// tirto.id/defisitpsikiater-dan-psikolog-sebarannya-terpusat-di-jawa-dpk2, Diunduh tanggal 15 Juni 2019.

bttps:// babel.bps.go.id/dynamictable/2018/01/23/402/jumlab-penduduk-provinsi-kep-bangka-belitungmenurut-kab-kota-2001-2020.btml, diunduh tanggal 6 Mei 2019.

Scientia: Jurnal Hasil Penelitian, Vol. 4, No. 1 (2019) | 129 
Sungailiat dan Belitung, layanan mereka berada di Rumah Sakit Jiwa Provinsi Kepulauan Bangka Belitung dan lainnya membuka praktek layanan konseling mandiri.

Kurangnya tenaga profesional dibidangnya ini membuat beberapa instansi dan masyarakat umum kesulitan dalam mendapatkan layanan tersebut. Ditambah lagi dengan kurangnya pengetahuan masyarakat dan juga kurang adanya sosialisasi terkait layanan konseling sendiri. Salah satu lembaga yang belum menerapkan layanan konseling dan sangat membutuhkan layanan ini adalah Lembaga Pembinaan Khusus Anak (LPKA) di Pangkalpinang Provinsi Kepulauan Bangka Belitung. ${ }^{5}$ Padahal layanan ini sangat dibutuhkan bagi remaja-remaja yang berada di dalam tahanan.

Hurlock berpendapat bahwa salah satu ciri pada masa remaja merupakan masamasa periode perubahan, ${ }^{6}$ kemudian Hurlock juga mengemukakan bahwa ada empat perubahan yang bersifat universal. Pertama, tingkat emosi yang meningkat intensitasnya, hal ini bergantung pada perubahan fisik dan psikologis. Kedua, perubahan pada tubuh, minat serta peran yang diharapkan oleh kelompok sosial, ini akan berdampak pada timbulnya permasalahan. Ketiga, berubahnya perilaku serta minat, maka nilai-nilai yang didalam diri juga akan ikut berubah. Keempat, pada masa ini remaja cukup merasa kebingungan pada tiap terjadinya perubahan baik, remaja menuntut dan menginginkan kebebasan namun mereka masih takut dan belum memiliki tanggung jawab penuh akan akibat yang terjadi.

Dikemukakan oleh Conger bahwa Perkembangan sosial remaja lebih percaya dan melibatkan kelompok teman sebaya dibandingkan terhadap orangtua. Remaja akan lebih banyak menghabiskan waktu di luar rumah seperti bersekolah, kegiatan ekstrakurikuler dan bermain bersama teman. Pendapat yang disampaikan Conger semakin memberi penguatan bahwa peran kelompok teman sebaya lebih besar saat memasuki masa-masa remaja. Pengaruh lingkungan berperan cukup kuat dalam menentukan perilaku remaja meskipun secara kognitif, remaja telah mencapai tahap yang memadai untuk menentukan tindakan sendiri, akan tetapi penentuan diri remaja

\footnotetext{
${ }^{5}$ Wawancara dengan Suyatno, M (Pimpinan LPKA)., tanggal 14 September 2018 di Kantor Lembaga Pembinaan Khusus Anak (LPKA) Pangkalpinang.

6 Hurlock. E B., Psikologi Perkembangan Sepanjang Rentang Kehidupan. Edisi kelima, Alih Bahasa: Istiwidayanti dan Soedjarwo (Jakarta: Erlangga, 1997), hlm. 207.
} 
Layanan Konseling Kelompok dalam Meningkatkan Psychological Well-Being Remaja di Lembaga Pembinaan Khusus Anak (LPKA) Pangkalpinang

dalam berperilaku masih banyak dipengaruhi oleh tekanan dari kelompok teman sebaya. ${ }^{7}$

Di LPKA, para remaja yang berhadapan dengan hukum kurang terfasilitasi dengan baik terkait layanan psikologis atau konseling. Rutinitas keseharian mereka banyak diisi dengan kegiatan-kegiatan positif lainnya, mulai dari berolahraga, membaca buku, mengaji, dan beberapa kali dalam seminggu mereka diberikan penyuluhan baik dari dinas-dinas terkait. Namun hal ini belum cukup bagi remaja binaan yang berada di LPKA karena kebanyakan mereka merasa malu dan bingung memikirkan bagaimana kehidupan selanjutnya setelah kembali ke masyarakat sehingga rasa kepercayaan diri dan penerimaan diri menurun, bahkan ada yang terkesan acuh (kurang menyesali perbuatan) karena merasa jika nanti kembali ke lingkungan rumah sudah tidak ada lagi yang memperdulikan mereka ${ }^{8}$ artinya kesejahteraan psikologisnya (psychological well-being) tidak terpondasi dengan baik lagi.

Layanan konseling dapat dilakukan secara individual maupun kelompok, dan layanan konseling kelompok dirasakan lebih efisien dalam penerapannya. ${ }^{9}$ Banyak keuntungan yang didapat dari layanan konseling kelompok ini diantaranya dalam satu kali kegiatan dapat memberikan manfaat kepada sejumlah orang dan dinamika perubahan yang terjadi saat layanan konseling kelompok terkesan menarik perhatian karena adanya interaksi antar individu anggota kelompok. ${ }^{10}$

\section{B. Konseling Kelompok}

\section{Pengertian Konseling Kelompok}

Layanan konseling kelompok merupakan layanan konseling perorangan namun dilaksanakan dalam suasana kelompok dan terjadi hubungan konseling yang hangat, terbuka dan penuh keakraban. ${ }^{11}$ Konseling kelompok adalah suatu proses kegiatan kelompok melalui interaksi sosial yang dinamis diantara anggota kelompok dengan

\footnotetext{
${ }^{7}$ Papalia, D E., Olds, S. W., \& Feldman, Ruth D., Human development (8th ed.). (Boston: McGraw-Hill, 2001).

8 Wawancara dengan Mulya (Mahasiswi PPLK IAIN SAS BABEL), tanggal 14 September 2018 di Masjid Lembaga Pembinaan Khusus Anak (LPKA) Pangkalpinang.

${ }^{9}$ Farid Mushadi, Psikologi Konseling, (Yogyakarta: IRCiSoD, 2012), hal. 249.

${ }_{10}$ Abror Sodik, Pengantar Bimbingan dan Konseling, (Yogyakarta: Aswaja Pressindo, 2017), hlm. 121.

${ }^{11}$ Ibid, hlm. 123.
} 
tujuan untuk membahas masalah yang dialami setiap anggota kelompok sehingga ditemukan arah serta cara pemecahan masalah yang tepat dan memuaskan. ${ }^{12}$

Selain itu, konseling kelompok juga merupakan upaya pemberian bantuan yang sifatnya untuk pencegahan serta pengembangan kemampuan pribadi sebagai bentuk dari pemecahan masalah secara kelompok atau bersama-sama dari seorang konsleor kepada klien. ${ }^{13}$ Dalam menentukan jumlah anggota kelompok, konselor dapat menetapkan sesuai dengan kemampuan dan keefektifan proses dari konseling artinya penetapan jumlah kelompok bersifat fleksibel dan dapat disesuaikan dengan kondisi yang ingin diciptakan oleh konselor dan klien. ${ }^{14}$

Layanan konseling kelompok dapat dirumuskan sebagai bentuk layanan kelompok dalam membantu menyelesaikan masalah pribadi anggota kelompok dengan memanfaatkan dinamika kelompok. ${ }^{15}$ Dinamika kelompok yaitu suatu gambaran kualitas hubungan yang positif, bergulir dan dinamis yang dapat mendorong kehidupan suatu kelompok. Dinamika kelompok dapat ditandai dari hal - hal berikut ini: 16

- Kelompok diwarnai dengan semangat yang tinggi dan kerjasama yang baik.

- Memiliki saling kepercayaan yang tinggi antaranggota kelompok.

- Bersikap seperti sahabat yang saling mengerti dan menerima tujuan bersama.

- Memiliki rasa aman dan nyaman sehingga mendorong rasa setia di setiap anggota kelompok.

- Menjalin komunikasi yang efektif.

- Terlibat dalam suasana berpikir, bersikap bertanggung jawab serta bertindak agar tercapai tujuan kelompok.

- Jika timbul persaingan maka persaingan tersebut merupakan persaingan yang kompetitif dan sehat.

\footnotetext{
12 Sisca Folastari \& Itsar Bolo Rangka, Prosedur Layanan Bimbingan dan Konseling Kelompok (Panduan Praktis Menyelurub), (Bandung: Mujahid Press, 2016), hlm. 21.

${ }^{13}$ Namora Lumongga Lubis \& Hasnida, Konseling Kelompok (Jakarta: Kencana,2016), hlm 25.

14 Ibid, hlm 78.

15 Sisca Folastari \& Itsar Bolo Rangka, Prosedur Layanan Bimbingan dan Konseling Kelompok (Panduan Praktis Menyeluruh) (Bandung: Mujahid Press, 2016), hlm. 22.

16 Ibid, hlm. 10.
} 
Layanan Konseling Kelompok dalam Meningkatkan Psychological Well-Being Remaja di Lembaga Pembinaan Khusus Anak (LPKA) Pangkalpinang

\section{Faktor-faktor yang Mempengaruhi Konseling Kelompok}

Faktor-faktor yang mempengaruhi keberhasilan dari pelaksanaan konseling kelompok, antara lain: ${ }^{17}$

a. Membina harapan, munculnya harapan akan membantu tumbuhnya rasa optimis dalam diri, klien akan belajar memahami potensi dirinya dan kemudian mengembangkannya, hal ini juga akan memunculkan rasa keterlibatan dalam kelompok dan akan saling membantu anggota satu dengan lainnnya.

b. Universalitas, semua orang dikelompok tersebut memiliki masalah yang sama dan tiap klien harus menyadari bahwa bukan hanya dirinya yang memiliki masalah. Untuk itu klien harus paham bahwa masalah dalam kehidupan itu diperlukan untuk menjadi tantangan agar mampu menghadapi dan mengatasi masalah yang dihadapi.

c. Pemberian informasi, meliputi pengalaman dari rekan kelompok, bantuan pemecahan masalah yang ditawarkan oleh konselor.

d. Altruisme, yaitu take and give atau proses saling memberi dan menerima. Klie diharapkan dapat merasakan bahwa banyak masukan, semangat dan kebaikan dari rekan lainnya dalam proses konseling, akan memberikan hal yang sama pada rekan lainnya pula sehingga ada feedback dalam konseling kelompok.

e. Pengulangan korektif keluarga primer, hal ini dimaksudkan agar dapat menjalin hubungan emosional antar-anggota kelompok dan konselor. Dengan adanya kedekatan secara emosional dapat saling mendukung dan akhirnya nanti tiap anggota kelompok dapat mencoba hal baru dalam berhubungan dengan orang lain.

f. Pengembangan teknik sosialisasi, masing-masing anggota kelompok akan belajar cara berkomunikasi dengan efektif, hal ini akan membantu tiap anggota kelompok dalam memahami orang lain.

g. Peniruan tingkah laku, tiap anggota kelompok mendapatkan figure yang positif yang dapat ditiru. Hal ini akan menguntungkan anggota kelompok karena memudahkan dalam mempelajari tingkah laku baru.

\footnotetext{
${ }^{17}$ Ibid., hlm. 74-76.
} 
h. Belajar menjalin hubungan interpersonal, disini akan mempelajari cara mengekspresikan diri sesuai dengan situasi, memberi kesempatan untuk mampu memberi respon atas apa yang didapatkan dari anggota kelompok serta meningkatkan sensitivitas.

i. Kohesivitas kelompok, ada rasa diterima dalam kelompok, membuat interaksi makin optimal dan tidak akan ada keraguan dalam hal keterbukaan.

j. Katarsis, mampu mengungkapkan perasaan baik positif ataupun negatif, sehingga pengungkapan perasaan ini dapat berdampak pada penyadaran emosi yang harus dikeluarkan (ekspresif).

k. Faktor-faktor eksistensial, banyak hal yang harus dicapai dalam kehidupan, untuk itu sebaiknya anggota kelompok dapat termotivasi dalam mengatasi masalah hidup.

\section{Psychological Well-Being}

\section{Pengertian Psychological Well-Being}

Menurut Ryff, psychological well-being merupakan istilah yang digunakan untuk menggambarkan kesehatan secara psikologis individu dengan dasar memenuhi kriteria fungsi psikologi positif. ${ }^{18}$ Menurut Snyder dan Lopez, kesejahteraan psikologis tidak hanya hilangnya penderitaan akan tetapi juga melibatkan keterikatan yang aktif dalam dunia, memiliki tujuan dan arti hidup terhadap orang lain ataupun objek lainnya. ${ }^{19}$ Dari beberapa pengertian diatas maka dapat disimpulkan bahwa psychological-well being atau kesejahteran psikologis merupakan gambaran psikologis yang sehat dan bahagia yang didapat dari terpenuhinya kebutuhan serta harapan dalam kehidupan.

\section{Aspek-Aspek Psychological Well-Being}

Dalam pshychological well-being terdapat enam aspek menurut Ryff, yaitu: ${ }^{20}$

\footnotetext{
18 Ryff, C. D.,"Happiness Is Everything or Is It? Explorations On The Meaning Of Pshichological Well-Being”, Journal of Happiness Studies, vol. 57 (1989), hlm. 1069-1081.

19 Tenggara, dkk.. "Kepuasan Kerja dan Kesejahteraan Psikologis Karyawan”, Jurnal Ilmiah Psikologi Industri dan Organisasi, vol. 10, no. 96 (2008), hlm. 330-341.

20 Papalia, D.E, Sally Wendkos Olds \& Ruth Duskin Feldman, Human Developmenatal. $8^{\text {th }}$ ed. (Philippines: Mc Graw Hill, 2002), hlm. 589.
} 
Layanan Konseling Kelompok dalam Meningkatkan Psychological Well-Being Remaja di Lembaga Pembinaan Khusus Anak (LPKA) Pangkalpinang

a. Penerimaan diri,

Aspek ini merupakan karakteristik utama dari setiap individu untuk mencapai aktualisasi diri. Penerimaan diri yang baik adalah mampu menerima diri apa adanya, mengetahui kelebihan serta kekurangan yang dimiliki diri dan memiliki pandangan yang baik tentang masa lalu.

b. Hubungan positif terhadap orang lain

Kemampuan ini harus dimiliki oleh individu sebagai karakteristik utama untuk saling mencintai dan percaya dengan orang lain. Mampu membuka diri dengan lingkungan, memiliki rasa cinta dan kasih sayang serta memiliki keyakinan atau rasa percaya yang akhirnya berdampak pada dapat menikmati kehidupan tanpa ada rasa tegang pada emosi diri.

c. Sikap mandiri dalam menentukan dan menjalani kehidupan

Individu yang mampu mandiri, mampu menolak tekanan sosial dan mengatur perilaku diri untuk memiliki standar pribadi. Yakin akan kemampuan yang dimiliki dan mampu memutuskan pemecahan masalah dalam suatu permasalahan yang dihadapi.

d. Penguasaan lingkungan

Merupakan kemampuan individu untuk mengembangkan diri untuk menjadi kreatif melalui aktivitas fisik ataupun mental dan peka terhadap lingkungan sekitar.

e. Memiliki tujuan hidup yang jelas

Individu memiliki target dan cita-cita dalam hidupnya, selain itu individu yang merasa bahwa kehidupan di masa lalu dan saat ini adalah hal yang bermakna.

f. Potensi diri.

Dalam hal ini, individu yang terbuka terhadap pengalaman baru berarti akan terus berkembang dan mampu melihat potensi - potensi yang ada didalam diri. 


\section{Masa Remaja}

\section{Kategori Remaja}

Periodisasi masa remaja (pubertas) dalam psikologi Islam disebut amrad ${ }^{21}$ yaitu fase persiapan bagi manusia untuk melakukan peran sebagai khalifah Allah di bumi adanya kesadaran akan tanggung jawab terhadap sesama mahluk. Menurut Hurlock, membagi masa remaja menjadi masa remaja awal (13 hingga 16 atau 17 tahun) dan masa remaja akhir (16 atau 17 hingga 18 tahun). Berbeda dengan pendapat Papalia dan Olds bahwa masa remaja merupakan masa transisi perkembangan dari masa anak-anak menuju masa dewasa yang pada umumnya dimulai dari usia 12 atau 13 tahun dan berakhir pada usia akhir belasan atau awal dua puluhan tahun. ${ }^{22}$

Dimasa remaja ini sering pula disebut dengan masa pubertas atau tahap "pematangan" sehingga banyak perubahan yang dialami oleh para remaja, mulai dari perubahan bentuk fisik seperti tinggi badan, mulai berkumis, muncul jakun, perubahan suara pada remaja laki-laki dan juga terjadi kematangan pada alat reproduksi. Perubahan-perubahan ini tentunya mempengaruhi perubahan sikap pada remaja diberbagai aspek antara lain sikap terhadap teman sebaya, terhadap orangtua, pendidikan dan juga lingkungan.

\section{Tugas Perkembangan Remaja}

Menurut William Kay, tugas-tugas perkembangan remaja sebagai berikut: ${ }^{23}$

a. Menerima fisik dan keragaman kualitas.

b. Mencapai kemandirian emosional dari orangtua dan figur lainnya yang memiliki otoritas.

c. Mampu mengembangkan keterampilan komunikasi interpersonal dan belajar bergaul dengan sosial secara individu ataupun kelompok.

d. Menemukan model yang dapat dijadikan identitas diri.

e. Menerima diri dan kemampuan yang dimiliki.

f. Mampu mengontrol diri (self-control).

${ }^{21}$ Fuad Anshori, Potensi-potensi Manusia, (Yogyakarta: Pustaka Pelajar, 2003), hlm. 153.

${ }^{22}$ Yudrik Jahja, Psikologi Perkembangan, Cetakan ke-4 (Jakarta: Prenadamedia, 2015), hlm. 220.

23 Ibid, hlm. 238. 
Layanan Konseling Kelompok dalam Meningkatkan Psychological Well-Being Remaja di Lembaga Pembinaan Khusus Anak (LPKA) Pangkalpinang

g. Mampu menyesuaikan diri atas perubahan dari masa kanak - kanak menuju remaja.

\section{Faktor yang Mempengaruhi Perilaku Menyimpang Pada Remaja}

Kelalaian orangtua dalam membimbing dan mengajarkan nilai-nilai agama, dapat membuat terjadinya penyimpangan-penyimpangan perilaku pada remaja, antara lain:24 Orangtua tidak mencontohkan kebiasaan beribadah (sholat berjamaah, membaca alquran, bersedekah dan lainnya); Pergaulan negatif (teman bergaul yang kurang memperhatikan nilai-nilai moral); Beredarnya film dan bacaan porno; Tidak dapat memanfaat waktu luang; Moralitas rendah; Kehidupan ekonomi keluarga yang morat-marit; Diperjualbelikan minuman keras serta obat-obat terlarang; Perceraian orangtua; Konflik antara anggota keluarga; Perlakuan orangtua yang buruk terhadap anak.

\section{E. Metodologi}

\section{Jenis Penelitian}

Penelitian ini merupakan penelitian ekperimen (experimental research) ${ }^{25}$ dengan bentuk pre-experimental design-one group pretest-posttest design. Pada desain ini terdapat pretest berupa pengisian angket sebelum diberi perlakuan yang berupa layanan konseling kelompok, dengan hal itu hasil perlakuan dapat diketahui dengan lebih akurat, karena adanya perbandingan antara sebelum dengan sesudah diberinya layanan konseling kelompok. ${ }^{26}$

\section{Subjek}

Penelitian ini dilakukan terhadap remaja di Lembaga Pembinaan Khusus Anak (LPKA) Pangkalpinang.

\section{Analisis Data}

Untuk menganalisis data maka digunakan Uji-t ( $t$-test). Uji-t dilakukan pada satu kelompok dikarenakan pada penelitian menggunakan one group pretest-posttest design. Teknis analisis ini digunakan untuk mengetahui adakah perbedaan skor pshychological

\footnotetext{
${ }^{24}$ Ibid., hlm. 225.

25 Sugiyono, Metode Penelitian Kuantitatif, Kualitatif dan R\&D (Bandung: Alfabeta, 2014), hlm. 73.

26 Ibid., hlm. 74.
} 
Siska Dwi Paramitha

well-being awal (pretest) dan skor akhir pshychological well-being (posttest). Gain Score yaitu perbedaan atau peningkatan skor yang diperoleh dengan cara menghitung selisih anatara skor pretest dan posttest.

\section{F. Hasil dan Pembahasan}

\section{Hasil Penelitian}

Berdasarkan rancangan one group pretest-postest design, eksperimen hanya dilakukan pada satu kelompok. Dalam penelitian ini dilakukan pertemuan sebanyak 8 (delapan) kali, diawali dengan melakukan pretest lebih dulu, dilanjutkan pemberian treatment (perlakuan) sebanyak enam kali dan diakhiri dengan posttest. Waktu pelaksanaan pemberian perlakuan selama 60 sampai dengan 120 menit.

Hasil analisis statistik uji-t diperoleh dari data untuk melihat perbandingan hasil dari data pretest dan posttest. Berikut hasil perhitungan Uji-t:

Tabel 1.

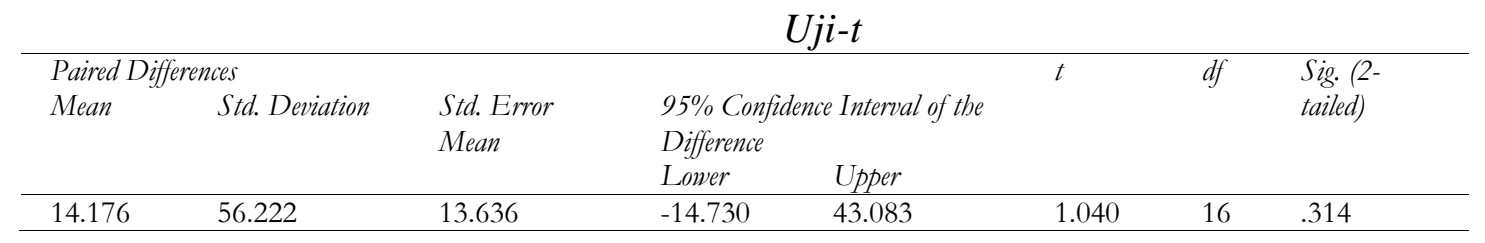

Nilai sig. $=0,314 \geq 0,05$ maka dapat disimpulkan bahwa hasil uji-t menunjukkan tidak terjadi peningkatan psychological well-being pada remaja LPKA Pangkalpinang antara sebelum dan sesudah diberikannya perlakuan berupa layanan konseling kelompok.

Tabel 2.

\begin{tabular}{ll|l|l|l}
\multicolumn{7}{c}{ Korelasi Uji-t } \\
\hline & $N$ & Correlation & Sig. \\
\hline Pair 1 & Pretest \& Posttest & 17 & .193 & .459 \\
\hline
\end{tabular}

Data di atas digunakan untuk melihat apakah ada hubungan antara data pretest dengan data posttest. Nilai signifikansi sebesar 0,459 > 0,05 maka dari data pretest dan posttest yang telah dilakukan sehingga dapat disimpulkan bahwa tidak ada hubungan antara kedua data tersebut.

Selanjutnya melihat hasil dari data sebaran nilai N-Gain score secara keseluruhan, didapat hasil uji sebagai berikut: 
Layanan Konseling Kelompok dalam Meningkatkan Psychological Well-Being Remaja di Lembaga Pembinaan Khusus Anak (LPKA) Pangkalpinang

Tabel 3.

Sebaran N-Gain Score

\begin{tabular}{lllll}
\hline No Sampel & Pretest & Posttest & Gain $(d)$ & $d^{2}$ \\
\hline 1 & 381 & 363 & -18 & -36 \\
2 & 417 & 415 & -2 & -4 \\
3 & 380 & 312 & -68 & -136 \\
4 & 374 & 411 & 37 & 74 \\
5 & 389 & 374 & -15 & -30 \\
6 & 421 & 431 & 10 & 20 \\
7 & 414 & 343 & -71 & -142 \\
8 & 394 & 441 & 47 & 94 \\
9 & 411 & 332 & -79 & -158 \\
10 & 377 & 328 & -49 & -98 \\
11 & 429 & 441 & 12 & 24 \\
12 & 431 & 438 & 7 & 14 \\
13 & 316 & 346 & 30 & 60 \\
14 & 416 & 293 & -123 & -246 \\
15 & 369 & 363 & -6 & -12 \\
16 & 390 & 446 & 56 & 112 \\
17 & 323 & 315 & -8 & -16 \\
\hline Sum & 6632 & 6392 & -240 & -480 \\
Mean & 390,12 & 376 & $-14,12$ & 28,24 \\
\hline
\end{tabular}

Dari sebaran nilai N-Gain Score terlihat dari ketujuh belas subjek selisih hasil antara pretest dan posttest cukup drastis. Terdapat tujuh orang mengalami perubahan yang positif yaitu subjek dengan nomor 4, 6, 8, 11, 12, 13 dan 16. Artinya perubahan yang positif dialami oleh tujuh orang tersebut ketika diberikan pretest kemudian diberikan perlakuan berupa layanan konseling kelompok dan selanjutnya diakhiri dengan posttest terdapat hasil yang cukup baik dimana adanya peningkatan pada psychological well-being setelah dilaksanakannya layanan konseling kelompok. Meskipun memang secara keseluruhan tidak tampak dengan jelas bahwa layanan konseling kelompok berperan besar dalam meningkatkan psychological well being. Dapat dilihat dari gambaran diagram berikut ini: 
Gambar.1

Diagram Gain Score

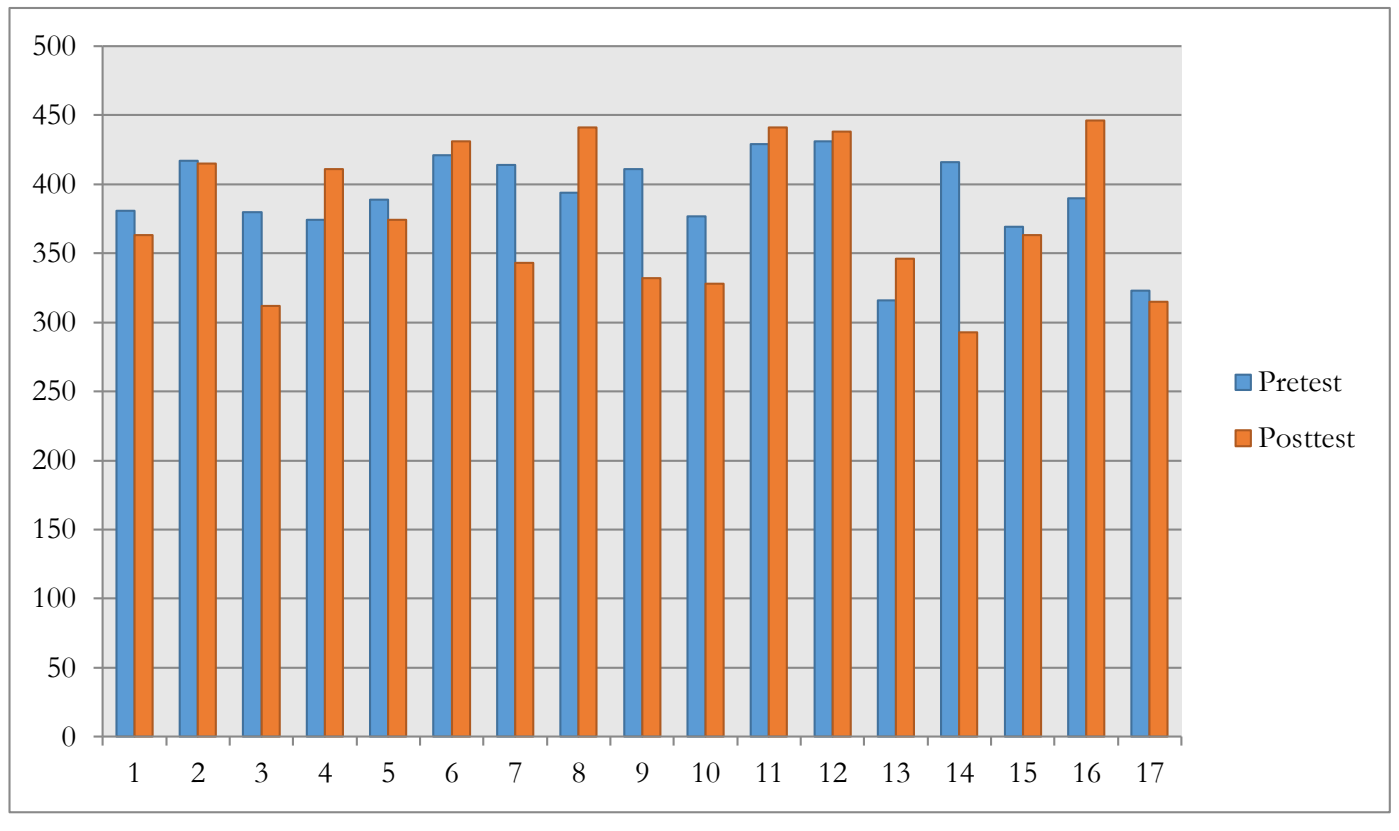

\section{G. Pembahasan}

Pelaksanaan dimulai dengan pretest pemberian angket awal untuk melihat kondisi psychological well being pada remaja tersebut. Hasil pretest yang didapat secara keseluruhan sebesar 390,12. Saat pelaksanaan pretest dari hasil observasi terlihat beberapa subjek saling mencoret lembar kuisioner yang telah dijawab oleh temannya. Ada pula yang meminta untuk diisikan oleh teman sebelahnya bahkan ada yang mejawab tanpa membaca pernyataan lebih dulu, meski sudah diingatkan oleh peneliti untuk mengisi sesuai dengan "perasaan" di kehidupan yang dialami dan tidak sembarangan dalam menentukan pilihan namun subjek kurang mau mendengarkan dan mengikuti aturan yang telah diberikan. Suasana pengerjaan kuesioner memang terlihat kurang serius dalam menjawab setiap pernyataan meskipun suasana sekitarnya cukup kondusif.

Selanjutnya remaja binaan diberikan perlakuan berupa layanan konseling kelompok dengan enam tema yang telah ditentukan sebelumnya. Konseling ini diberikan oleh konselor yang cukup berpengalaman dibidangnya dengan tujuan perlakuan yang diberikan tidak akan dapat diarahkan oleh peneliti secara langsung. Diawal pelaksanaan pemberian layanan konseling kelompok, konselor memberitahukan aturan main dalam pelaksaanaannya antara lain: setiap individu harus 
Layanan Konseling Kelompok dalam Meningkatkan Psychological Well-Being Remaja di Lembaga Pembinaan Khusus Anak (LPKA) Pangkalpinang

dan mau terbuka, menceritakan atau membagikan pengalamannya, tidak saling mencela, memberikan waktu untuk rekan yang sedang menyampaikan pendapatnya, tetap tenang dan mengikuti instruksi yang diberikan. Nyatanya dalam pelaksanaan pemberian layanan konseling kelompok, konselor harus berulang kali mengingatkan agar tetap menghargai pendapat rekan yang mau berbagi dan tidak mentertawakan atau mencela pengalaman yang diceritakan. Dalam melakukan interaksi yang baik terhadap orang lain maka dibutuhkan perilaku memberikan penghargaan. ${ }^{27}$

Tema pertama di pertemuan awal membahas tentang penerimaan diri. Konselor meminta remaja binaan untuk menyebutkan kelebihan dan kekurangan masingmasing namun mereka masih kesulitan untuk menceritakan dan menyampaikan pendapat mereka, sehingga konselor harus memulai dengan meminta mereka untuk menuliskan lebih dulu kelebihan dan kekurangan yang ada pada diri masing-masing di kertas yang sudah disediakan kemudian membacakannya di depan teman-teman, selanjutnya teman harus menanggapi dengan positif cerita yang telah dibagikan. Dari ketujuhbelas konselee yang mencoba untuk menuliskan kelebihan dan kekurangannya, hampir rata-rata kesulitan dalam menemukan kelebihan yang ada pada dirinya. Artinya secara pribadi, seseorang yang kurang mampu menilai dirinya sendiri dengan baik maka kemungkinan kepercayaan diri yang dimiliki tergolong kurang baik. Menurut Maslow pemenuhan kebutuhan manusia tentunya bermula dari kebutuhan primer hingga ke aktualisasi diri, dengan tercapainya pemenuhan kebutuhan ini maka akan membawa rasa kepercayaan diri yang baik pada diri. ${ }^{28}$

Pertemuan selanjutnya yang membahas tentang kemampuan membina hubungan positif terhadap orang lain. Dipertemuan ini konselor membuka pertemuan dengan menceritakan berbagai macam cara konselor dalam membina hubungan yang positif terhadap orang lain, kemudian konselor menunjuk salah satu remaja binaan dengan inisial D, untuk menceritakan bagaimana pengalaman hubungan sosialnya. D menceritakan sebelum mendapat binaan di LPKA dirinya sudah menikah, D juga memiliki banyak teman namun karena $\mathrm{D}$ terbujuk oleh rayuan teman sehingga ia

${ }^{27}$ Budi Andayani, "Pentingnya Budaya Menghargai Dalam Keluarga”, Buletin Psikologi, Tahun X, No. 1 (Juni 2002), hlm. 1.

28 Ibid.

Scientia: Jurnal Hasil Penelitian, Vol. 4, No. 1 (2019) | 141 
melakukan kejahatan hingga harus berhadapan dengan hukum. Saat ini kondisi hubungannya dengan teman tersebut sudah tidak pernah bertemu lagi bahkan istrinya pun ikut meninggalkan dirinya.

Usia remaja memang merupakan masa dimana remaja akan lebih mempercayai hubungan dengan sesama teman atau relasi. Keberhasilan remaja menjalin hubungan pertemanan ditentukan pula oleh perkembangan konsep diri sosialnya. ${ }^{29}$ Konsep diri sosial yaitu pendapat individu tentang orang lain memandang dirinya dalam kemampuan sosialnya. Kesuksesan dalam pergaulan sosial mampu meningkatkan kepercayaan diri dan akan mengembangkan konsep diri yang positif. ${ }^{30}$ Dalam perkembangan sosial remaja, memang remaja akan lebih terbuka terhadap teman sebaya namun emosi yang belum stabil atau masih labil sering membuat terjadinya perselisihan atau pertengkaran yang malah berdampak pada saling pukul dan lain sebagainya.

Pada pertemuan selanjutnya, konselor memberikan tema tentang sikap mandiri dalam menentukan dan menjalani kehidupan. Untuk dapat menentukan pendirian maka seseorang membutuhkan pengenalan diri lebih baik. Melalui pengenalan diri secara pribadi, maka akan membantu dalam pemecahan suatu masalah yang dihadapi. Dari pertemuan konseling kelompok di sesi ini, setiap konseli menyampaikan bahwa mereka mampu mandiri dan tidak membutuhkan bantuan orang lain. Mereka merasa mampu menentukan pilihan sendiri namun akibat dari lingkungan pergaulan yang salah maka pola pemikiran menjadi cenderung menyimpang dan akhirnya salah mengambil langkah dalam pemecahan masalah. Padahal, seseorang yang memiliki sikap mandiri yang kuat dapat bertanggung jawab, menyesuaikan diri pada perubahan lingkungan baru, berani menghadapi masalah dan resiko, dan tidak mudah terpengaruh atau tergantung pada orang lain. ${ }^{31}$

Penguasaan lingkungan menjadi tema di pertemuan yang keempat, sebagai seorang remaja pada umumnya harus memiliki kreatifitas yang tinggi dan juga lebih

\footnotetext{
${ }^{29}$ Resti Asweni dan Khirani, "Korelasi Antara Konsep Diri Sosial Dengan Hubungan Sosial”, Jurnal Ilmiah Konseling, vol. 2, no. 1 (2013), hlm. 38.

${ }^{30}$ Elida Prayitno, Psikologi Perkembangan Remaja (Padang: Angkasa Raya, 2006), hlm. 123-124.

31 Nuryoto, "Kemandirian Remaja Ditinjau dari Tahap Perkembangan, Jenis Kelamin, dan Peran Jenis”, Jurnal Psikologi (1993), hlm. 49.
} 
Layanan Konseling Kelompok dalam Meningkatkan Psychological Well-Being Remaja di Lembaga Pembinaan Khusus Anak (LPKA) Pangkalpinang

peka terhadap lingkungan. Suatu interaksi sosial yang dilakukan oleh seseorang saling memberikan dampak atau pengaruh terhadap orang lain oleh sebab itu dapat mengubah ataupun memperbaiki perilaku individu. ${ }^{32}$

Remaja binaan di sesi ini kembali harus saling berinteraksi dengan menyampaikan pengalaman-pengalaman mereka mengenai penguasaan lingkungan dan kepekaan mereka terhadap lingkungan. Saat ini beberapa dari remaja menyampaikan adanya perasaan sedih karena "terbuang" oleh keluarga. Anggota keluarga tidak lagi mengujungi mereka. Akan tetapi ada pula yang sebaliknya justru semakin mendapatkan perhatian dari keluarga dan merasa lebih bersemangat untuk dapat menjalani hari-hari di dalam pembinaan serta menunggu masa binaan selesai.

Dialog juga dilanjutkan dengan mengetahui tujuan hidup, cita-cita serta makna hidup dari masa lalu, masa kini dan masa yang akan datang. Konselor juga menanyakan apa yang terjadi di kehidupan masa lalu mereka sebelum berhadapan dengan hukum seperti saat ini, hampir semua menjawab merasa terjebak dengan pergaulan yang salah. Kurang mendapat perhatian dari orangtua, kondisi keluarga broken bome, serta kondisi finansial yang kurang terpenuhi. Konselor kembali menanyakan satu persatu cita-cita yang ingin diraih pada masa yang akan datang, beberapa dari mereka menjawab ingin memiliki kehidupan yan lebih baik lagi, membahagiakan orangtua, mencari kerja, menjauhi pertemanan yang bisa memberikan dampak buruk pada mereka, melanjutkan sekolah dengan mengambil paket $C$.

Sesi konseling kelompok yang terakhir membahas tentang potensi diri. Untuk mengenali potensi diri seseorang maka harus digali lebih dulu kemampuankemampuan yang dimiliki agar dapat dikembangkan. Konseling kembali dilakukan dengan mengeksplor pendapat dari tiap remaja binaan. Konselor mulai dengan menanyakan pengalaman apa yang didapatkan selama berada di dalam pembinaan LPKA. Beberapa menanggapi dengan positif bahwa dengan mendapat binaan di

32 Pia Amanda Nurhusni, "Profil Penyesuaian Sosial Remaja yang Mengalami Kecanduan Mengakses Facebook", Indonesian Jurnal of Educational Counseling, vol. 1, no. 2 (2017), hlm. 130. 
LPKA mereka lebih merasa teratur, rajin beribadah, dapat kesempatan untuk membaca dan belajar dari perpustakaan keliling yang difasilitasi oleh LPKA.

Namun, ada pula yang menanggapi dengan biasa saja dan merasa bosan berada didalam LPKA ini. Kemudian dilanjutkan dengan mencari tahu kemampuan mereka masing-masing, dimulai dengan mencari hobi atau kegemaran mereka baik itu dibidang musik, olahraga, literasi ataupun lainnya. Sehingga konselor membantu para remaja binaan menemukan potensi diri mereka.

Dari perlakuan yang diberikan berupa layanan konseling kelompok ternyata secara kuantitatif didapatkan tidak adanya perbedaan dalam peningkatan psychological well being pada remaja di LPKA Pangkalpinang. Dari data yang didapat layanan konseling kelompok hanya memberikan sumbangan sebesar 4\%, artinya pemberian layanan konseling kelompok belum cukup memberikan peranan dalam meningkatkan psychological well being pada remaja di LPKA Pangkalpinang.

Keberhasilan dalam pemberian layanan konseling kelompok memang ditentukan oleh beberapa faktor-faktor pendukung agar dapat terlaksana dengan baik, namun banyak faktor pula yang dapat menjadi keterbatasan dalam pelaksanaan layanan konseling kelompok ini. Dalam pelaksanaannya memang tidak semudah yang dibayangkan dan dipaprkan secara teori, bahwasannya konselor harus membangun hubungan kedekatan lebih dulu agar dapat masuk ke dalam lingkungan konselee. Faktanya baru didua pertemuan terakhir, konselee terlihat baru mau membuka diri, banyak menanggapi konselor dan lebih kooperatif, maka dapat disimpulkan penyesuaian diri para konselee pada orang baru memang membutuhkan waktu sehingga layanan konseling kelompok tidak bisa digunakan pada kondisi dimana konselee dan konselor belum saling mengenal lebih dalam.

Konselee yang dihadapi disini adalah remaja yang berhadapan dengan hukum dimana kasus yang mereka lakukan antara lain: pencurian, pengeroyokan, kesusilaan, narkotika dan perlindungan anak. Hal ini didukung dengan pendapat Pietrofesa et al ${ }^{33}$ bahwa keterbatasan dalam konseling kelompok salah satunya adalah karena kurang cocok digunakan untuk menangani masalah perilaku yang ekstrim. Akan tetapi

\footnotetext{
${ }^{33}$ M. Edi kurnanto. Konseling Kelompok. Bandung: Alfabeta, 2014. hlm.32.
} 
Layanan Konseling Kelompok dalam Meningkatkan Psychological Well-Being Remaja di Lembaga Pembinaan Khusus Anak (LPKA) Pangkalpinang

kembali lagi, jika merunut fenomena yang ada bahwa setiap individu yang telah menghadapi hukum dan melalui masa tahanan yang cukup lama, lama kelamaan akan terasing baik oleh masyarakat ataupun keluarga sendiri oleh sebab itu dibutuhkan pendampingan-pendampingan yang tepat agar bisa mengarahkan ke arah yang lebih baik dalam hidup dan salah satu upayanya dengan melakukan berbagai macam jenis konseling agar dapat membantu dan mengarahkan ke arah yang lebih baik lagi.

\section{H. Catatan Penutup}

Dari paparan di atas memang belum terlihat dampak langsung dan signifikan dalam pemberian layanan konseling kelompok dalam meningkatkan psychological wellbeing pada remaja di LPKA dengan alasan berbagai macam faktor yang menjadi permasalahan saat berada di lapangan. Namun, layanan konseling tetap harus dibina dan dibangun untuk membantu remaja binaan agar dapat meningkatkan psychological well-being.

Psychological well-being amat dibutuhkan bagi tiap individu agar tidak hanya sehat secara fisik namun secara psikologis juga mendapatkan kesehatan yang optimal. Psychological well-being yang optimal akan menopang kepribadian yang positif. Hal ini akan membawa ke arah kehidupan yang lebih baik. Banyak cara yang bisa dilakukan untuk meningkatkan psychological well-being salah satunya melalui konseling dan terapi lainnya. 


\section{Daftar Pustaka}

Adam, Aulia, Defisit Psikiater dan Psikolog Sebarannya Terpusat di Jawa. 6 Mei 2019. bttps: / tirto.id/ defisit-psikiater-dan-psikolog-sebarannya-terpusat-di-jawa-dpk.2,

Diunduh tanggal 15 Juni 2019.

Andayani, Budi. Pentingnya Budaya Menghargai Dalam Keluarga, (Buletin Psikologi, Tahun X, No. 1 Juni 2002) ISSN: $0854-7108$.

Anshori, Fuad, Potensi-Potensi Manusia, Yogyakarta: Pustaka Pelajar, 2003.

Asweni, Resti dan Khirani. Korelasi Antara Konsep Diri Sosial Dengan Hubungan Sosial. Jurnal Ilmiah Konseling. Vol. 2, No. 1 Januari 2013.

Folastari, Sisca,\& Itsar Bolo Rangka, Prosedur Layanan Bimbingan dan Konseling Kelompok (Panduan Praktis Menyelurub), Bandung: Mujahid Press, 2016.

bttps:// babel.bps.go.id/dynamictable/2018/01/23/402/jumlab-penduduk-provinsi-kepbangka-belitung-menurut-kab-kota-2001-2020.btml, diunduh tanggal 6 Mei 2019.

Jahja, Yudrik, Psikologi Perkembangan, Jakarta: Prenadamedia, Cetakan ke-4, september 2015.

Lubis, Namora Lumongga \& Hasnida, Konseling Kelompok, (Jakarta: Kencana, 2016.

Kurnanto, M. Edi, Konseling Kelompok, Bandung: Alfabeta, 2014.

Mulya, wawancara tentang pandangan remaja yang menghadapi hukum di Masjid Lembaga Pembinaan Khusus Anak (LPKA) Pangkalpinang di LPKA Pangkalpinang. 14 September 2018.

Mushadi, Farid, Psikologi Konseling, Yogyakarta: IRCiSoD, 2012.

Nurhusni, Pia Amanda. Profil Penyesuaian Sosial Remaja yang Mengalami Kecanduan mengakses facebook. Indonesian Jurnal of Educational Counseling. Volume 1, No. 2 Juli 2017.

Nuryoto. Kemandirian Remaja Ditinjau dari Tahap Perkembangan, Jenis Kelamin, dan Peran Jenis. Jurnal Psikologi. Yogyakarta: Fakultas Psikologi UGM. 1993.

Papalia, D E., Olds, S. W., \& Feldman, Ruth D. Human development (8th ed.). Boston: McGraw-Hill, 2001.

Prayitno, Elida. 2006. Psikologi Perkembangan Remaja. Padang: Angkasa Raya.

Primastika,Widia. Penyebab Kriminalitas Anak: Kurang Kasib Sayang \& Pengakuan Sosial,29 Juli 2018, https://amp.tirto.id/penyebab-kriminalitas-anak-kurang-kasib-sayangpengakuan-sosial-cP3FI. Diunduh 11 Maret 2019.

Ryff, C. D.,"Happiness Is Everything or Is It? Explorations On The Meaning Of Pshichological Well Being”. Journal of Happiness Studies. 57 Tahun 1989.

Simanjuntak. Julianto. Pusat Konseling di Setiap Kota. 3 Februari 2016, http:/ / juliantosimanjuntak.com/index.php/artikel/ renungan-catatan-harian/237-1pusat-konsleing-di-setiap-kota, Diunduh tanggal 11 Maret 2019.

Sodik, Abror, Pengantar Bimbingan dan Konseling, Yogyakarta: Aswaja Pressindo, 2017.

Sugiyono, Metode Penelitian Kuantitatif, Kualitatif dan R\&D, Bandung: Alfabeta, 2014. 
Layanan Konseling Kelompok dalam Meningkatkan Psychological Well-Being Remaja di Lembaga Pembinaan Khusus Anak (LPKA) Pangkalpinang

Suyatno, wawancara tentang situasi dan kondisi di Lembaga Pembinaan Khusus Anak (LPKA) Pangkalpinang di LPKA Pangkalpinang. 14 September 2018.

Tenggara, dkk.. Kepuasan Kerja dan Kesejahteraan Psikologis Karyawan. Jurnal Ilmiah Psikologi Industri dan Organisasi, 10, 96. 2008. 